\title{
The effects on bacterial translocation and tissue damage of selenium treatment in an experimental intestinal ischaemia-reperfusion model
}

\author{
Emine Yıldırım, M.D., ${ }^{1}$ ○ Hilal Özer, M.D., ${ }^{2}$ ๑ IIter Özer, M.D., ${ }^{3}$ \\ (D) Adil Koyuncu, M.D., ${ }^{4}$ () Timur Yıldırım, M.D. ${ }^{5}$
}

\begin{abstract}
'Department of General Surgery, University of Health Sciences, Gaziosmanpaşa Training and Research Hospital, İstanbul-Turkey 2Department of General Surgery, University of Health Sciences Turkey, Ankara Training and Research Hospital, Ankara-Turkey ${ }^{3}$ Department of General Surgery, Eskişehir Osmangazi University Faculty of Medicine, Eskişehir-Turkey ${ }^{4}$ Department of General Surgery, University of Health Sciences, Haseki Training and Research Hospital, İstanbul-Turkey ${ }^{5}$ Department of Orthopedics and Traumatology, University of Health Sciences, Baltalimani Bone Diseases Training and Research Center, İstanbul-Turkey
\end{abstract}

\begin{abstract}
BACKGROUND: The free oxygen radicals formed with reperfusion following intestinal ischaemia are extremely toxic for the cells. Glutathione peroxidase, an important enzyme that prevents the formation of reactive oxygen species, requires selenium as a co-factor. This study aims to demonstrate the effects of selenium administration on reducing ischaemia-reperfusion damage.

METHODS: In this study, 28 male Wistar rats were separated into four groups. To Groups 3 and 4, sodium selenite at the dose of $10 \mu \mathrm{g} / \mathrm{kg} /$ day was administered intraperitoneally for five days. In Groups I and 3, laparotomy was applied, and in Groups 2 and 4 , following laparotomy, ischaemia was created by clamping the superior mesenteric artery for 45 mins, then reperfusion was provided for 90 mins. Blood, liver and ileum samples were taken from all the animals for examination of malondialdehyde. For examination of bacterial translocation, liver, spleen and mesenteric lymph node tissue samples were taken. A sample taken from the ileum was examined histopathologically.
\end{abstract}

RESULTS: There was determined to be significantly more bacterial translocation in the mesenteric lymph nodes of the ischaemia-reperfusion group $(p<0.05)$. In the histopathological evaluation, the score in the ischaemia-reperfusion group was significantly higher than the scores in the other groups $(p<0.05)$. Elevated serum, liver and ileum malondialdehyde levels in the ischaemia-reperfusion group were significantly higher than those in the other groups $(p<0.05)$.

CONCLUSION: Selenium was seen to have decreased serum and tissue malondialdehyde levels and increased the histopathological damage developing in the intestines with ischaemia-reperfusion and thereby increased bacterial translocation.

Keywords: Bacterial translocation; ileum; ischaemia; reperfusion; selenium.

\section{INTRODUCTION}

Ischaemia is defined as reduced blood flow to the target organ or complete removal from the environment. This results in the absence of oxygen in the tissue. Intestinal ischaemia may develop in several clinical situations, such as acute mes- enteric ischaemia, hemorrhagic shock, necrotising enterocolitis, trauma and strangulated hernia. Ischaemia-reperfusion (I/R) damage is defined as the changes forming with blood flow and oxygenation provided again in tissue that has been temporarily exposed to ischaemia. ${ }^{[1,2]}$ Damage caused by ischaemia in the intestines develops in two stages. First, hypox-

Cite this article as: Yıldırım E, Özer H, Özer İ, Koyuncu A, Yıldırım T. The effects on bacterial translocation and tissue damage of selenium treatment in an experimental intestinal ischaemia-reperfusion model. Ulus Travma Acil Cerrahi Derg 2021;27:389-394.

Address for correspondence: Emine Yıldırım, M.D.

Gaziosmanpaşa Eğitim ve Araştırma Hastanesi, Genel Cerrahi Kliniği, İstanbul, Turkey

Tel: +90 212 - 9453000 E-mail: opdreyildirim@gmail.com

Ulus Travma Acil Cerrahi Derg 2021;27(4):389-394 DOI: 10.14744/tjtes.2020.5890I Submitted: 20.03.2020 Accepted: 10.05.2020

Copyright 202I Turkish Association of Trauma and Emergency Surgery 
ia and hyponutrition may occur in the ischaemia period. In this situation, energy production with aerobic metabolism is impaired, adenosine triphosphate (ATP) production is reduced, adenosine monophosphate (AMP) increases, and then lactic acid accumulates, leading to metabolic acidosis. ${ }^{[3,4]}$ In the second stage, reperfusion is provided with blood flow to the ischaemic tissue, and oxygen is re-introduced. In parallel to this, reactive oxygen species (ROS) production increases because of a lower antioxidative agent concentration in the ischaemic cells. ROS and endothelial dysfunction may cause oxidative stress supporting DNA damage and local inflammatory response. Inflammatory cascades and oxidative stress may cause a subsequent cytokine storm and this causes cell death by damaging cellular structures. ${ }^{[5]}$

Potential mechanisms of I/R damage include insufficient oxygenation at the cellular and tissue level and the formation of ROS and the emergence of inflammatory mediators with activation of the xanthine oxidase system following reperfusion. [6] Although reperfusion of ischaemic tissues is necessary for repair mechanisms, it has been shown to worsen the acute ischaemic injury of ROS expression. ROS plays a role in the pathogenesis of structural and functional changes that occur in the tissues associated with various pathological processes, primarily mesenteric $\mathrm{I} / \mathrm{R}$ damage. ${ }^{[7,8]}$ The cell response in I/R damage depends on the severity of the total tissue damage. [9] As the duration of ischaemia increases, so the damage formed also increases. The cell damage caused by reperfusion following long-term ischaemia may lead to apoptosis, autophagia, necrosis and necroptosis. ${ }^{[10,11]}$

In normal conditions, the intestinal mucosa is a barrier preventing the passage of bacteria and endotoxins from the intestinal lumen to systemic tissue and organs. However, in conditions of intestinal I/R, trauma, burn, or infection, bacteria cross this barrier causing systemic infection, and consequently, multiorgan dysfunction syndrome (MODS) and multiorgan failure syndrome (MOFS) may develop. ${ }^{[12,13]}$ In the majority of patients who die because of systemic inflammatory response syndrome (SIRS), MODS or MOFS in which a septic focus cannot be identified, bacteremia has been determined. ${ }^{[12]}$ This observation suggests that the bacteria and endotoxins could originate from the gastrointestinal system.

The intestine plays an important role in protecting the nutritional and physiological functions of the organism, participates in the stress reaction following trauma, and is the source of MODS. ${ }^{[14]}$ In addition to the other effects of I/R damage, increasing bacterial translocation from the intestine also leads to systemic infections. ROS, which is responsible for I/R damage and causes this much damage, are free radicals of oxygen origin. Reactive oxygen species include superoxide, hydrogen peroxide, hydroxyl radical, nitric oxide, singlet oxygen, hypochlorous acid, alcoxyl and peroxyl. ${ }^{[15]}$ ROS are produced endogenously in the organism, associated with immune system activation, inflammation, stress, excessive ex- ercise, ischaemia, infection, cancer and aging. ${ }^{[6]}$ When the capacity of the antioxidant defence mechanism in the body is exceeded, they may lead to various impairments. Through interaction with all cell components and all classes of biomolecules, such as carbohydrates, lipids, proteins and DNA, ROS causes structural and metabolic changes in cells. ${ }^{[17]}$ When ROS enters into a reaction with cholesterol and unsaturated fatty acids in the cell membrane, lipid peroxidation is initiated. Lipid peroxidation may damage the cell membrane by impairing the viscosity and permeability of the membrane. Thus, severe tissue damage develops following ischaemia. ${ }^{[15,17]}$

There is a defence system in the organism against the formation of ROS, and the formation of lipid peroxides is prevented in this way. The three main enzyme systems preventing the formation of ROS are superoxide dismutase, catalase and glutathione peroxidase (GPx). By superoxide dismutase metabolising superoxide radical and catalase metabolising hydrogen peroxide, accumulation in the body is prevented. GPx prevents the start of lipid peroxidation and prevents the progression of peroxidation by metabolising lipid hydroperoxides which form as a result of peroxidation. ${ }^{[18,19]}$ Selenium (Se), which was previously known to have toxic and carcinogenic properties, has been evaluated as a significant and useful element for biological systems as the result of recent studies. ${ }^{[20]}$

Se is primarily found in hemoglobin and in the antioxidant property of the structure of GPx enzyme, which plays a role in the prevention of some metabolic diseases and cancer types. The biological importance of Se is that it is a co-factor of this enzyme. In each subunit, GPx contains one atom of Se in the form of selenocysteine, which plays a role in the breakdown of hydrogen peroxide $\left(\mathrm{H}_{2} \mathrm{O}_{2}\right)$ to water within the cell. ${ }^{[2]}$ Selenium deficiency decreases GPx activity and changes the response of the tissue to oxidative stress. ${ }^{[6]}$ Se can support the protection of cells and macromolecules against oxidative damage. ${ }^{[22]}$ In animal models and human trials of selenium deficiency, it has been emphasised that selenium supplementation is beneficial in improving the selenium status of the body. ${ }^{[23-25]}$ In the light of this information, this study aims to investigate the effects of selenium on ileum histology, bacterial translocation and lipid peroxidation in an experimental I/R model in rats.

\section{MATERIALS AND METHODS}

To conduct this study, ethical approval was granted by the Local Ethics Committee. In this study, 28 adult male Wistar rats, each weighing 250-300 gr, were used. The animals were separated into four groups as the control group $(n=6$, Group I), the I/R group ( $n=6$, Group 2 ), the selenium injection group $(n=8$, Group 3$)$ and the $I / R+$ selenium injection group $(n=8$, Group 4). The animals were kept at room temperature under a 12-hour light/dark cycle. All the rats were anaesthesized with $50 \mathrm{mg} / \mathrm{kg}$ ketamine and $7 \mathrm{mg} / \mathrm{kg}$ rompun was administered intramuscularly; then, a laparotomy was performed under sterile conditions. 
The Group I subjects were applied with laparotomy only under sterile conditions. In Group 2, after the laparotomy, the superior mesenteric artery was clamped for 45 mins to create ischaemia; then reperfusion was provided for 90 mins. The Group 3 subjects were administered $10 \mu \mathrm{g} / \mathrm{kg} / \mathrm{day}$ sodium selenate intraperitoneally for five days before the laparotomy. The Group 4 subjects were administered $10 \mu g / \mathrm{kg} /$ day sodium selenate intraperitoneally for five days; then the laparotomy was applied, during which the superior mesenteric artery was clamped for 45 mins to create ischaemia; then reperfusion was provided for 90 mins.

After completion of these periods, a thoracotomy was applied to all the rats, and a blood sample was taken from the heart of each animal for biochemical analysis. The blood samples taken were assayed for malondialdehyde (MDA). Samples were taken from the ileum and liver tissues and frozen in liquid nitrogen for the measurement of MDA and selenium absorption. Samples for histopathological examinations were taken from the distal ileum and stored in 10\% formaldehyde. Mesenteric lymph node, liver and spleen tissue samples were taken under sterile conditions for microbiological examination for the evaluation of bacterial translocation.

\section{Histopathological Evaluation}

The ileum samples were fixed in 10\% formaldehyde; then slices were prepared and stained with hematoxylin-eosin. Mucosal damage, hyperemia/hemorrhage and inflammation degree were evaluated by a pathologist blinded to the sample groups using the scoring system described by Chui et al. ${ }^{[26]}$

\section{Microbiological Evaluation}

The liver, spleen and mesenteric lymph node samples were placed in $2 \mathrm{ml}$ Brain Heart Infusion Broth; then weights were measured and homogenised. The samples were then seeded in blood agar and Eosin-Methylene-Blue-Lactose-Sucrose agar, and the cultures were incubated in aerobic conditions. Bacterial production was checked at 24 and 48 hours, and the bacteria strains were identified. Colonisation was stated as the number of colony-forming units per milliliter of tissue (CFU/ml tissue).

\section{Biochemical Evaluation}

The biochemical evaluation was based on the level of MDA, which is a lipid peroxidation product. By measuring the MDA level in tissue, blood and bodily fluids, the lipid peroxidation and thereby oxidative stress were objectively evaluated. ${ }^{[27]} \mathrm{Se}-$ rum MDA levels were measured with the thiobarbituric acid (TBA) method. The results were stated as nmol MDA $/ \mathrm{ml} .{ }^{[28]}$

MDA levels in the intestinal mucosa of liver tissue were measured spectrophotometrically with the TBA method in liver homogenates prepared with $1.15 \% \mathrm{KCL}$ solution. The results were calculated as nmol/MDA/gram. ${ }^{[29]}$

For the measurement of selenium atomic absorption in intestinal mucosa and liver tissue, the samples were mixed with nickel nitrate and surfactant; then placed in a granite oven. The light formed from selenium transmitted from a hollow cathode lamp was absorbed in proportion to the amount of selenium in the solution at a specific wavelength. The amount of absorbed energy was directly proportional to the selenium concentration. The results were calculated as ngSe/gr tissue. ${ }^{[30]}$

\section{Statistical Analysis}

The measurements were compared according to the mean and standard deviation values of the variables. The data of the variables were determined to conform to a normal distribution, so to investigate differences between groups, the Kruskal Wallis test was used. To determine from which group a difference originated, the Mann-Whitney $U$ test and the Tukey B test were applied. In the comparison of categorical variables, ratios were used, and to evaluate whether or not there were any differences between ratios. The Pearson Chisquare test was applied. A value of $p<0.05$ was accepted as statistically significant.

\section{RESULTS}

In the histopathological evaluation, there was evident mucosal damage and leukocyte clustering in the ileum samples of Group 2 (Fig. I). The histopathological scores of Group 2
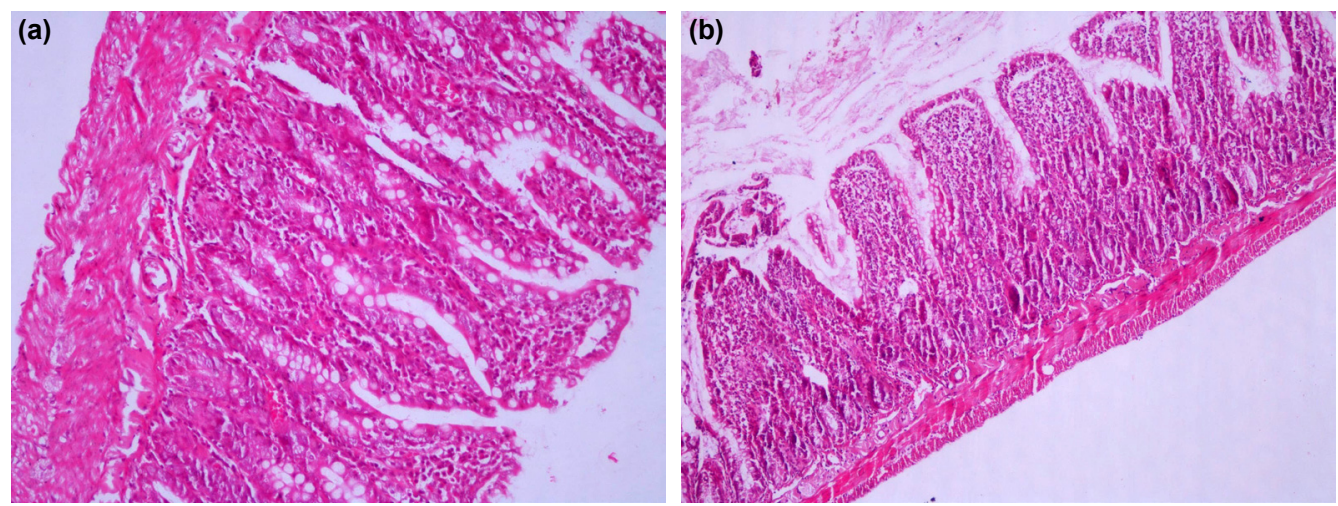

Figure 1. (a) Ischaemia-reperfusion group; intense inflammation and neutrophil aggregation in the ileum section, stained with hematoxylin-eosin, 20X, (b) Ischaemia-reperfusion+Selenium injection group; preserved intestine close to normal, $10 \mathrm{X}$. 
Table I. Histopathological scores

\begin{tabular}{lc}
\hline Groups & Histopathological scores \\
\hline Control group & $2.3 \pm 0.13$ \\
Ischaemia-reperfusion group & $7.2 \pm 0.47$ \\
Selenium injection group & $2.8 \pm 1.8$ \\
Ischaemia-reperfusion + & $1.6 \pm 0.74$ \\
Selenium injection group & \\
\hline
\end{tabular}

were statistically significantly higher than the scores of the other groups $(p<0.05)$. The histopathological scores are shown in Table I.

In the microbiological examination, production was seen in the mesenteric lymph nodes of nine (32.1\%) of the 28 subjects. Mesenteric lymph node production was seen in each of the six subjects in Group 2 (100\%). There was determined to be statistically significantly more bacterial translocation in the mesenteric lymph nodes of Group 2 than in the other groups $(p<0.05)$. The micro-organisms produced were Escherichia coli and enterococci. No production was determined in the spleen, and there was production in the liver in two subjects (7.1\%) in Group 2, with no statistically significant difference determined between the groups.

The MDA values are shown in Table 2. When the serum, ileum, and liver MDA values were compared, the MDA values in Group 2 were statistically significantly higher than those of the other groups $(p<0.001)$.

The liver selenium values in Groups 3 and 4, which received the selenium injections, were 2-fold higher than those of the groups that did not receive the injections. The mean selenium atomic absorption in Groups I-4 was 865.4, 828.2, 1674.8 and $166 \mathrm{I} . \mathrm{I} \mathrm{ngSe} / \mathrm{g}$, respectively. The ileum selenium atomic absorption mean values in Groups 3 and 4 were statistically significantly higher than Groups I and $2(p<0.00 I)$. The ileum selenium atomic absorption mean values in Groups I-4 were 206.6, 222.2, 301.2 and $303.3 \mathrm{ngSe} / \mathrm{g}$, respectively.

\section{DISCUSSION}

Ischaemia reperfusion damage is the result of blood flow restarting in tissue that was previously ischaemic, paradoxically causing cell dysfunction and death. I/R damage is not limited to local damage to organs, such as the heart, lungs, kidneys, brain and intestines, but also has the potentially fatal effects of systemic damage in distant organs and multiple organ failure. Although the effects of I/R damage have been shown to have been successfully reduced in experimental animal models, clinical studies have not been as promising. ${ }^{[3]}$

Several studies have shown that oxygen-derived free radicals are the mediators responsible for the reperfusion component in I/R damage. ${ }^{[3,4,32,33]}$ With the evident status of the ROS concept and perfusion damage mechanism, the question of how the damage can be prevented has come to prominence. The gastrointestinal system has antioxidant enzymes, which prevent the system that creates ROS. One of these enzymes is GPx, which catalyses ROS destruction. Selenium is a co-factor of this enzyme, and when it is deficient, enzyme activity is reduced. ${ }^{[34]}$

When intestinal I/R damage forms, it has been shown that as a source of gastrointestinal system bacteria and endotoxemia, it may lead to MODS and sepsis. ${ }^{[35]}$ Selenium is a basic element in several physiological functions and has an antioxidant effect as a critical co-factor for the function of the glutathione peroxidase enzyme, which plays a role in glutathione oxidisation. It has been shown that selenium could be effective in preventing I/R damage in the heart, lungs and kidneys. ${ }^{[3-38]}$ Schoenberg et al. showed that mucosal lesions developed with reperfusion two hours after intestinal ischaemia. In that study, it was stated that hypoxia caused mucosal lesions and the intestinal functions deteriorated with reperfusion. ${ }^{[39]}$ In an experimental model of ischaemia reperfusion damage, Bauer et al. ${ }^{[40]}$ created ischaemia by clamping the superior mesenteric artery in rats. There was determined to be a decrease in mean blood pressure after reperfusion an increase in plasma lactate levels, and a reduction in erythrocyte GPx levels. In the group administered selenium, the decrease in blood pressure and increase in plasma lactate levels were lower, and the

Table 2. MDA levels in serum and tissue

\begin{tabular}{lccc}
\hline & \multicolumn{2}{c}{ MDA value [Mean \pm SD (nmol/g)] } \\
\cline { 2 - 4 } Groups & Serum & lleum & Liver \\
\hline Control group & $25.6 \pm 2.3$ & $14 \pm 1$ & $15.6 \pm 1.9$ \\
Ischaemia-reperfusion group & $37 \pm 5.2^{*}$ & $20.6 \pm 5.9^{*}$ & $25.5 \pm 1.7^{*}$ \\
Selenium injection group & $18.4 \pm 4.2$ & $12 \pm 2.8$ & $13.5 \pm 1$ \\
Ischaemia-reperfusion + Selenium injection group & $23.6 \pm 2.8$ & $15.8 \pm 3.5$ & $19.8 \pm 2.4$ \\
P-value & $<0.001$ & $<0.003$ & $<0.001$ \\
\hline MDA: Malondialdehyde; SD: Standard deviation. & & &
\end{tabular}


fall in GPx levels was seen to be less. Akman et al. ${ }^{[4]}$ created invagination in an experimental rat model, and reported that selenium prevented the oxidative damage formed in invagination by increasing antioxidant enzyme activity. In another study conducted on rats by Erbil et al., ${ }^{[42]}$ selenium treatment in the ischaemia model created was shown to reduce oxidative stress. Similarly, in a study of cerebral ischaemia by Mehta et al.," ${ }^{[3]}$ selenium was shown to have protected mitochondrial function following focal cerebral ischaemia, stimulated mitochondrial biogenesis and reduced infarct volume.

In the current study, while mucosal destruction, separation and loss of mucosa, and leukocyte clustering increased in the I/R group, the appearance of the intestinal mucosa was close to normal in the group administered with selenium, and there was increased selenium atomic absorption in the intestines and liver. The blood, ileum and liver MDA levels in the selenium group were at the same level as those of the control group. These results suggest that selenium assists in the prevention of lipid peroxidation by GPx.

Oztürk et al. ${ }^{[38]}$ reported that intraperitoneal selenium supplementation significantly reduced intestinal damage of $I / R$ origin in rats and prevented I/R-related bacterial translocation. I/R damage in the small intestine causes the production of local cytokines and ROS which induce endothelial responses which pull neutrophils in the circulation to the damaged region. ${ }^{[8,15]}$ This includes a complex interaction between intestinal wall integrity and bacterial translocation. In a study by Lelli et al., ${ }^{[44]}$ iron deferoxamine, which is an antioxidant like selenium, was used to limit lipid peroxidation mediated by specific oxidant to the organ in post-chemical injuries to the intestines in neonatal rats. Albrecht et al. ${ }^{[45]}$ suggested that peroxynitrite could be directly neutralised by selenium. It was shown in their study that pre-treatment with selenium protected intestinal integrity and reduced bacterial translocation with a mechanism probably started by preventing lipid peroxidation after I/R. In the current study, the bacterial translocation that occurred following the failure of the barrier in the intestine was significantly reduced in the mesenteric lymph nodes in the group that received selenium.

In conclusion, the results of this study of ischaemia-reperfusion damage in the intestines showed that selenium reduced MDA levels, and the mucosal damage developing associated with I/R damage and thereby reduced bacterial translocation.

Ethics Committee Approval: Approval for this study was granted from local ethics committee in Feb 2003 (reg: 82I).

Peer-review: Internally peer-reviewed.

Authorship Contributions: Concept: I.Ö., E.Y.; Design: E.Y.; Supervision: E.Y., I.Ö.; Materials: E.Y., H.Ö.; Data: E.Y., H.Ö.; Analysis: E.Y., T.Y.; Literature search: E.Y., A.K., Writing: E.Y.; Critical revision: E.Y., H.Ö., I..Ö.

Conflict of Interest: None declared.
Financial Disclosure: The authors declared that this study has received no financial support.

\section{REFERENCES}

1. Yasuhara H. Acute mesenteric ischemia: the challenge of gastroenterology. Surg Today 2005;35:185-95.[CrossRef]

2. Fishman JE, Sheth SU, Levy G, Alli V, Lu Q, Xu D, et al. Intraluminal nonbacterial intestinal components control gut and lung injury after trauma hemorrhagic shock. Ann Surg 2014;260:1112-20. [CrossRef]

3. Grace PA. Ischaemia-reperfusion injury. Br J Surg 1994;81:637-47.

4. Kukreja RC, Hess ML. The oxygen free radical system: from equations through membrane-protein interactions to cardiovascular injury and protection. Cardiovasc Res 1992;26:641-55. [CrossRef]

5. Ornellas FM, Ornellas DS, Martini SV, Castiglione RC, Ventura GM, Rocco PR, et al. Bone marrow-derived mononuclear cell therapy accelerates renal ischemia-reperfusion injury recovery by modulating inflammatory, antioxidant and apoptotic related molecules. Cell Physiol Biochem 2017;41:1736-52. [CrossRef]

6. Noack H, Possel H, Chatterjee S, Keilhoff G, Wolf G. Nitrosative stress in primary glial cultures after induction of the inducible isoform of nitric oxide synthase (i-NOS). Toxicology 2000;148:133-42. [CrossRef]

7. Carden DL, Granger DN. Pathophysiology of ischaemia-reperfusion injury. J Pathol 2000;190:255-66. [CrossRef]

8. Rose S, Floyd RA, Eneff K, Bühren V, Massion W. Intestinal ischemia: reperfusion-mediated increase in hydroxyl free radical formation as reported by salicylate hydroxylation. Shock 1994;1:452-6. [CrossRef]

9. Gottlieb RA. Cell death pathways in acute ischemia/reperfusion injury. J Cardiovasc Pharmacol Ther 2011;16:233-8. [CrossRef]

10. Lopez-Neblina F, Toledo AH, Toledo-Pereyra LH. Molecular biology of apoptosis in ischemia and reperfusion. J Invest Surg 2005;18:335-50.

11. Zhu J, Yao K, Wang Q, Guo J, Shi H, Ma L, et al. Ischemic postconditioning-regulated mir-499 protects the rat heart against ischemia/reperfusion injury by inhibiting apoptosis through PDCD4. Cell Physiol Biochem 2016;39:2364-80. [CrossRef]

12. Zhi-Yong S, Dong YL, Wang XH. Bacterial translocation and multiple system organ failure in bowel ischemia and reperfusion. J Trauma 1992;32:148-53. [CrossRef]

13. Bone RC. Sepsis, the sepsis syndrome, multi-organ failure: a plea for comparable definitions. Ann Intern Med 1991;114:332-3. [CrossRef]

14. Kelleher ZT, Potts EN, Brahmajothi MV, Foster MW, Auten RL, Foster WM, et al. NOS2 regulation of LPS-induced airway inflammation via S-nitrosylation of NF-\{kappa\}B p65. Am J Physiol Lung Cell Mol Physiol 2011;301:L327-33. [CrossRef]

15. Valko M, Leibfritz D, Moncol J, Cronin MT, Mazur M, Telser J. Free radicals and antioxidants in normal physiological functions and human disease. Int J Biochem Cell Biol 2007;39:44-84. [CrossRef]

16. Pham-Huy LA, He H, Pham-Huy C. Free radicals, antioxidants in disease and health. Int J Biomed Sci 2008;4:89-96.

17. Cheeseman KH, Slater TF. An introduction to free radical biochemistry. Br Med Bull 1993;49:481-93. [CrossRef]

18. Southorn PA, Powis G. Free radicals in medicine. I. Chemical nature and biologic reactions. Mayo Clin Proc 1988;63:381-9. [CrossRef]

19. Webster NR, Nunn JF. Molecular structure of free radicals and their importance in biological reactions. Br J Anaesth 1988;60:98-108. [CrossRef]

20. Vernie LN. Selenium in carcinogenesis. Biochim Biophys Acta 1984;738:203-17. [CrossRef]

21. Navarro-Alarcón M, López-Martínez MC. Essentiality of selenium in the human body: relationship with different diseases. Sci Total Environ 2000;249:347-71. [CrossRef]

22. Rayman MP. Selenium and human health. Lancet 2012;379:1256-68.

23. Clausen J, Nielsen SA. Comparison of whole blood selenium values and 
erythrocyte glutathione peroxidase activities of normal individuals on supplementation with selenate, selenite, L-selenomethionine, and high selenium yeast. Biol Trace Elem Res 1988;15:125-38. [CrossRef]

24. Tanguy S, Morel S, Berthonneche C, Toufektsian MC, de Lorgeril M, Ducros V, et al. Preischemic selenium status as a major determinant of myocardial infarct size in vivo in rats. Antioxid Redox Signal 2004;6:792-6. [CrossRef]

25. Xing Y, Liu Z, Yang G, Gao D, Niu X. MicroRNA expression profiles in rats with selenium deficiency and the possible role of the $\mathrm{Wnt} / \beta$-catenin signaling pathway in cardiac dysfunction. Int J Mol Med 2015;35:143-52.

26. Chiu CJ, McArdle AH, Brown R, Scott HJ, Gurd FN. Intestinal mucosal lesion in low-flow states. I. A morphological, hemodynamic, and metabolic reappraisal. Arch Surg 1970;101:478-83. [CrossRef]

27. Morgan RA, Manning PB, Coran AG, Drongowski RA, Till GO, Ward $\mathrm{PD}$, et al. Oxygen free radical activity during live E. coli septic shock in the dog. Circ Shock 1988;25:319-23.

28. Hammouda AE, Soliman SF, Tolba KA, el-Kabbany ZA, Makhlouf MS. Plasma concentrations of lipid peroxidation products in children with acute lymphoblastic leukemia. Clin Chem 1992;38:594-5. [CrossRef]

29. Mihara M, Uchiyama M. Determination of malonaldehyde precursor in tissues by thiobarbituric acid test. Anal Biochem 1978;86:271-8. [CrossRef]

30. Mengübaş K, Diab NA, Gökmen G, Ataman OY, Cavdar A, Cin S. Selenium status of healthy Turkish children. Biol Trace Elem Res 1996;54:163-72. [CrossRef]

31. Abu-Amara M, Gurusamy KS, Hori S, Glantzounis G, Fuller B, Davidson $\mathrm{BR}$. Pharmacological interventions versus no pharmacological intervention for ischaemia reperfusion injury in liver resection surgery performed under vascular control. Cochrane Database Syst Rev 2009;(4):CD007472. [CrossRef]

32. McCord JM. Oxygen-derived free radicals in postischemic tissue injury. N Engl J Med 1985;312:159-63. [CrossRef]

33. Reilly PM, Schiller HJ, Bulkley GB. Pharmacologic approach to tissue injury mediated by free radicals and other reactive oxygen metabolites. Am J Surg 1991;161:488-503. [CrossRef]

34. Toufektsian MC, Boucher F, Pucheu S, Tanguy S, Ribuot C, Sanou D, et al. Effects of selenium deficiency on the response of cardiac tissue to ischemia and reperfusion. Toxicology 2000;148:125-32. [CrossRef]

35. Border JR, Hassett J, LaDuca J, Seibel R, Steinberg S, Mills B, et al. The gut origin septic states in blunt multiple trauma (ISS $=40$ ) in the ICU. Ann Surg 1987;206:427-48. [CrossRef]

36. Tassopoulos A, Chalkias A, Papalois A, Iacovidou N, Xanthos T. The effect of antioxidant supplementation on bacterial translocation after intestinal ischemia and reperfusion. Redox Rep 2017;22:1-9. [CrossRef]

37. Soncul H, Kaptanoğlu M, Oz E, Halit V, Bilgehan A, Cayci B, et al. The role of selenium added to pulmonary preservation solutions in isolated guinea pig lungs. J Thorac Cardiovasc Surg 1994;108:922-7. [CrossRef]

38. Oztürk C, Avlan D, Cinel I, Cinel L, Unlü A, Camdeviren H, et al. Selenium pretreatment prevents bacterial translocation in rat intestinal ischemia/reperfusion model. Pharmacol Res 2002;46:171-5. [CrossRef]

39. Schoenberg $\mathrm{MH}$, Beger HG. Reperfusion injury after intestinal ischemia. Crit Care Med 1993;21:1376-86. [CrossRef]

40. Bauer P, Belleville-Nabet F, Watelet F, Dubois F, Larcan A. Selenium, oxygen-derived free radicals, and ischemia-reperfusion injury. An experimental study in the rat. Biol Trace Elem Res 1995;47:157-63. [CrossRef]

41. Akman H, Somuncu S, Dikmen G, Ayva Ş, Soyer T, Doğan P, et al. Protective effect of selenium on intussusception-induced ischemia/reperfusion intestinal oxidative injury in rats Turk J Med Sci 2010;40:391-7.

42. Erbil G, Ozbal S, Sonmez U, Pekcetin C, Tugyan K, Bagriyanik A, et al. Neuroprotective effects of selenium and ginkgo biloba extract (EGb761) against ischemia and reperfusion injury in rat brain. Neurosciences (Riyadh) $2008 ; 13: 233-8$.

43. Mehta SL, Kumari S, Mendelev N, Li PA. Selenium preserves mitochondrial function, stimulates mitochondrial biogenesis, and reduces infarct volume after focal cerebral ischemia. BMC Neurosci 2012;13:79. [CrossRef]

44. Lelli JL Jr, Pradhan S, Cobb LM. Prevention of postischemic injury in immature intestine by deferoxamine. J Surg Res 1993;54:34-8. [CrossRef]

45. Albrecht S, Zimmermann T, Ockert D, Oelschläger S, Heinzmann J, Schilling JU. Does selenium prevent peroxynitrite formation from $\mathrm{NO}$ in vascular surgery interventions? A clinical study. [Article in German]. Med Klin (Munich) 1997;92:10-1. [CrossRef]

\section{DENEYSEL ÇALIŞMA - ÖZ}

\section{Deneysel intestinal iskemi-reperfüzyon modelinde selenyum tedavisinin bakteriyel translokasyon ve doku hasarı üzerinde etkileri \\ Dr. Emine Yıldırım, ${ }^{1}$ Dr. Hilal Özer, ${ }^{2}$ Dr. İlter Özer, ${ }^{3}$ Dr. Adil Koyuncu, ${ }^{4}$ Dr. Timur Yıldırım ${ }^{5}$}

${ }^{1}$ T.C. Sağlık Bakanlığı Gaziosmanpaşa Eğitim ve Araştırma Hastanesi, Genel Cerrahi Kliniği, İstanbul

${ }^{2}$ T.C. Sağıı Bakanlığı Ankara Eğitim ve Araştırma Hastanesi, Genel Cerrahi Kliniği, Ankara

${ }^{3}$ Osmangazi Üniversitesi Tıp Fakültesi, Gastroenteroloji Cerrahisi Bilim Dalı, Eskişehir

${ }^{4}$ T.C. Haseki Eğitim ve Araştırma Hastanesi, Genel Cerrahi Kliniği, İstanbul

${ }_{5}^{5}$ Sağlık Bilimleri Üniversitesi, Baltalimanı Kemik Hastalıkları Sağlık Uygulama ve Araştırma Merkezi, İstanbu

AMAÇ: İntestinal iskemi sonrası reperfüzyon gerçekleşmesi ile oluşan serbest oksijen radikalleri hücre için son derece toksiktir. Glutatyon peroksidaz ise reaktif oksijen türlerinin oluşumunu engelleyen önemli enzimlerdendir ve kofaktör olarak selenyuma ihtiyaç duyar. Çalışmamızın amacı selenyum uygulanmasının iskemi-reperfüzyon hasarını azaltııı etkisini göstermektir.

GEREÇ VE YÖNTEM: Çalışmada 28 adet erkek Wistar sıçan kullanıldı. Denekler dört gruba ayrıldı. Üçüncü ve dördüncü gruba beş gün süre ile 10 mikrogram $/ \mathrm{kg} /$ gün sodyum selenat intraperitoneal olarak verildi. Birinci ve üçüncü grup deneklere laparotomi yapıldı, ikinci ve dördüncü gruptaki deneklere ise laparotomi sonrası superiyor mezenterik arter 45 dakika klempe edilip iskemi oluşturuldu, ardından 90 dakika reperfüzyon sağlandı. Deneklerden malondialdehit için kan, karaciğer ve ileum örneği alındı. Bakteriyel translokasyon için karaciğer, dalak ve mezenterik lenf nodu doku örnekleri alındı, ayrıca ileumdan alınan örnek ile histopatolojik inceleme yapıldı.

BULGULAR: İskemi-reperfüzyon grubunda mezenterik lenf nodlarında bakteriyel translakasyon diğer gruplardan anlamlı derecede fazla idi $(p<0.05)$. Histopatolojik değerlendirmelere bakıldığında yine iskemi-reperfüzyon grubunda skor diğer gruplardan anlamlı derecede yüksekti $(p<0.05)$. Serum, karaciğer ve ileum malondialdehit düzeyleri de iskemi-reperfüzyon grubundaki yüksekliğe bağlı olarak gruplar arasında anlamlı farkllık gösterdi $(p<0.05)$. TARTIŞMA: Çalışmamız selenyumun serum ve doku MDA düzeylerini düşürdüğü, bağırsaklarda iskemi-reperfüzyon hasarı ile gelişen histopatolojik hasarı ve buna bağlı bakteriyel translokasyonu azalttığı göstermiştir.

Anahtar sözcükler: Bakteriyel translokasyon; ileum; İskemi; reperfüzyon; selenyum.

Ulus Travma Acil Cerrahi Derg 2021;27(4):389-394 doi: 10.14744/tjtes.2020.5890 I 